Volume 11, Nomor 1, Mei 2019, pp $61 \quad$ - 76 Copyright (C) 2017 Jurnal Akuntansi Maranatha, Program Studi Akuntansi, Fakultas Ekonomi,Universitas Kristen Maranatha. ISSN 2085-8698 | e-ISSN 2598-4977. http://journal.maranatha.edu

\title{
Pengaruh Nation Branding "Pesona Indonesia" Terhadap Preferensi Tujuan Wisata Masyarakat Kota Bandung
}

\author{
Steffi Priani Sugi \\ Fakultas Ekonomi Program Magister Manajemen-Univ.Katolik Parahyangan \\ (Jl. Merdeka No.30, Bandung) \\ stevipsugi@gmail.com \\ Astia Putri \\ Fakultas Ekonomi Program Studi Manajemen-Univ.Katolik Parahyangan \\ (J1. Ciumbeleuit No. 94, Bandung) \\ astiaanggraini@gmail.com
}

\begin{abstract}
Tourism is one industry that has the potential to drive the economy and provide a positive impact on more developed national development. Nation Branding program carried out by the Ministry of Tourism and Creative Economy (Kemenparekraf) to improve the image and attract tourists to various destinations to Indonesians themselves. The research method used in this study is descriptive explanatory method using questionnaires and observations. The sampling method used is nonprobiliy sampling. in the study there are independent or independent variables (X) namely Nation Branding consisting of exports, governance, investment, culture, people, and tourism. The dependent variable (Y) is the preference of the tourist destination. The results showed that the nation branding variable had a significant influence on tourist destination preferences. The independent variable of the most influential nation branding is culture and tourism. The independent variable of the most influential nation branding is culture and tourism. The author recommends to increase the tagline "Pesona Indonesia" with more massive and effective marketing consistently. In addition, it is necessary to have optimal support and cooperation between tourism stakeholders to be in line with what they want to convey by the tagline "Pesona Indonesia".
\end{abstract}

Keywords: Nation Branding, Preferensi Tujuan Wisata, Pesona Indonesia, Indonesia.

\section{Pendahuluan}

Pada era globalisasi saat ini, sektor pariwisata yang sangat dinamis serta manfaat nilai strategisnya menjadi sektor andalan bagi pembangunan nasional ke depan. Perkembangan pariwisata memberikan dampak positif untuk suatu negara yang lebih baik, bahwa selama beberapa dekade terakhir pariwisata telah mengalami pertumbuhan dan perubahan. Terlihat pada tabel 1.1 mengenai pertumbuhan ranking devisa pariwisata yang bertambah setiap tahunnya. Hal tersebut menjadi salah satu industri yang 
berpotensi menggerakan perekonomian lebih baik dan maju di Indonesia.Pertumbuhan pariwsata Indonesia mengalami peningkatan setiap tahunnya. Pariwisata akan menjadi penghasil devisa terbesar negara diatas minyak \& gas bumi, batu bara, kelapa sawit, dan karet alam.

Pariwisata adalah kunci pembangunan dan kesejahteraan.Meningkatnya destinasi dan investasi di sektor tersebut menjadikan pariwisata adalah sektor unggulan juga sebagai faktor kunci dalam pendapatan ekspor, penciptaan lapangankerja, dan pengembangan usaha maupun infrastruktur pada suatu negara.Pariwisata mengalami ekspansi dan diversifikasi serta menjadi salah satu sektor ekonomi yang terbesar dan tercepat pertumbuhannya. Di tahun 2014, selain penghasil devisa negara sebanyak Rp120 Triliun, pariwisata telah memiliki kontribusi pada PDB Nasional sebesar 4\%, dengan jumlah tenaga kerja 8.7 juta. Kondisi kepariwsataan nasional tahun 2015 secara makro menunjukkan perkembangan yang terus meningkat terhadap PDB nasional sebesar $4.23 \%$ atau senilai $\mathrm{Rp}$ 461.36 Triliun dengan peningkatan devisa mencapai US\$ 11.9 Milyar, dan tenaga kerja pariwsata sebanyak 12.16 juta orang. Prospek kepariwisataan yang semakin cerah dan posisi strategis dalam kerangka pembangunan nasional, memberikan dorongan dan keharusan akan langkah langkah strategis untuk meningkatkan kinerja kepariwisataan nasional serta daya saing agar mampu menarik kunjungan para wisatawan.

Republik Indonesia adalah negara di Asia Tenggara yang dilintasi garis khatulistiwa dan berada di antara benua Asia dan Australia serta Samudera Pasifik dan Samudera Hindia ini merupakan negara kepulauan terbesar di dunia yang terdiri dari 13.466 pulau dengan 5 kepulauan besar dan 30 kelompok kepulauan kecil. Terbentang dari Sabang hingga Merauke menjadikan Indonesia memiliki gugusan - gugusan pulau yang menawan, melimpahnya sumber daya alam, adat dan budaya yang beraneka ragam, dikaruniai pegunungan indah dengan beribu - ribu meter tingginya di atas permukaan laut, serta surganya pesona bawah laut yang memiliki dua per tiga koral dan lokasi menyelam terbaik di dunia terdapat di Indonesia. Namun, tidak sedikit wisatawan nusantara lebih memilih untuk melakukan wisata ke mancanegara dibandingkan kedalam negeri sendiri.Hal tersebut dikarenakan adanya beberapa faktor salah satunya yaitu terkait citra atau image suatu negara.Untuk itu, nation branding yang kuat sebagai diferensiasi merupakan upaya yang dapat dilakukan untuk meningkatkan potensi pariwisata Indonesia.Nation branding dapat diistilahkan sebagai country branding yaitu sebagai sebuah identitas bangsa yang telah dikaji mendalam, diartikan, dan diinternalisasikan kepada seluruh negaranya, dan ditujukan untuk membangun citra sebuah negara serta meningkatkan daya saing sebuah negara (Akotia, 2011).

Promosi terkait nation branding pada Indonesia tidak hanya sekadar tagline, namun harus dilakukan secara konsisten dan pesan yang disampaikan harus tersktruktur, kuat, dan benang merahnya terdapat disetiap promosi.Selain itu, infrastruktur dan sumber daya manusia terkait juga menjadi salah satu kelemahan utama sektor pariwisata Indonesia. Jumlah wisatawan Indonesia yang berpergian ke luar negeri pada tahun 2015 meningkat 3\% dibandingkan dengan tahun 2014 atau sebesar 6,31 juta wisatawan. Tujuan wisata favorit wisatawan Indonesia terdiri dari lima negara Asia, yakni Singapura (31\%), Malaysia (25\%), kemudian China (13\%), selanjutnya Arab Saudi (7.5\%), dan Thailand sebesar 5.9\% (bisniswisata.co.id, 2016).

Saat ini, sebagaimana dilansir dalam Peraturan Pemerintah Republik Indonesia Nomor 50/2011 mengenai Rencana Induk Pembangunan Kepariwisataan Nasional Tahun 2010-2025, disebutkan bahwa Tujuan Pembangunan Kepariwisataan Nasional yaitu mengkomunikasikan destinasi pariwisata 
Indonesia dengan menggunakan media pemasaran secara efektif, efisien, dan bertanggung jawab. Sehubungan dengan hal tersebut, Kepariwisataan Indonesia telah mengusahakan media secara efektif dan efisien untuk mewujudkan suatu pencitraan yang baik pada Negara Indonesia.

Terkait dengan arah kebijakan pengembangan citra pariwisata Indonesia yang meliputi peningkatan dan pemantapan citra pariwisata Indonesia secara berkelanjutan maka diperlukan langkah strategis untuk meningkatkan dan memantapkan posisi citra pariwisata di Indonesia. Salah satunya melalui promosi, diplomasi, dan komunikasi, yaitu branding "Wonderful Indonesia" dan "Pesona Indonesia" yang telah resmi diluncurkan pada tanggal 1 Januari 2011 adalah janji pariwisata Indonesia kepada para wisatawan dengan segala aspek melalui naturalwonders, sensory wonders, cultural wonders, modern wonders dan adventurous wonders.

Selain berharap banyaknya kunjungan dari para wisatawan asing yang berwisata di Indonesia, industri pariwisata nasional dapat bergerak karena kontribusi kunjungan turis nusantara itu sendiri. Andil dari wisatawan nusantara atau domestik tidak dapat dianggap sebelah mata, data Kementerian Pariwisata menunjukan pada tahun 2014, perjalanan wisatawan nusantara mencapai 251.2 juta perjalanan dengan total pengeluaran Rp213.9 Triliun. Kondisi tersebut merupakan peningkatan sangat signifikan dari tahun sebelumnya yaitu sebesar Rp1.76,3 Triliun. Artinya pendapatan sektor pariwisata dan turis lokal jauh lebih tinggi dibandingkan dengan pendapatan devisa dari turis asing. Selain itu, biaya yang dikeluarkan para wisatawan lokal diyakini mampu menggerakan perekonomian daerah, karena perjalanan wisatawan domestik sebagian besar adalah ke daerah - daerah yang jangkauannya lebih luas ketimbang tujuan turis asing.

. Selaras dengan langkah tersebut, dapat disimpulkan nation branding "Pesona
Indonesia" dapat menentukan wisatawan nusantara untuk melakukan perjalanan liburan ke negaranya sendiri.Penelitian ini dilakukan untuk menganalisa apakah Branding "Pesona Indonesia" mempengaruhi preferensi tujuan destinasi wisata khususnya masyarakat Kota Bandung.

\section{Rumusan Masalah}

Berdasarkan latar belakang tersebut, rumusan masalah yang didapat sebagai berikut:

1. Bagaimana Persepsi Masyarakat Kota Bandungmengenai Branding "Pesona Indonesia"?

2. Bagaimana Preferensi Masyarakat Kota Bandung terhadap Tujuan Destinasi domestik?

3. Bagaimana pengaruh Branding "Pesona Indonesia" terhadap Preferensi Tujuan Wisata pada masyarakat Kota Bandung?

\section{Tujuan Penelitian}

1. Mengetahui Persepsi Masyarakat Kota Bandung terhadap Branding "Pesona Indonesia".

2. Mengetahui Preferensi Masyarakat Kota Bandung terhadap Tujuan Destinasi Domestik.

3. Mengetahui pengaruh Branding "Pesona Indonesia" terhadap Preferensi Tujuan Wisata pada masyarakat Kota Bandung.

\section{Kerangka Teoritis dan Hipotesis}

\section{Branding}

Aktivitas branding sangat penting untuk mencapai tujuan perusahaan secara jangka panjang, bahwa konsumen tidak cukup hanya dengan sisi fungsi melainkan terdapat faktor lain yaitu terkait persepsi pada citra suatu merek itu sendiri.Branding is an association created in the mind of a 
potential buyer, between a product and its desired characteristics". Aktivitas branding secara tersinkronisasi dengan apa yang disampaikan oleh suatu merek sampai dibenak konsumen.

\section{Nation Branding}

Nation branding adalah sekumpulan teori dan penerapannya bertujuan untuk mengukur, membangun, dan mengatur reputasi suatu negara.Hal tersebut berhubungan dengan place branding.Branding bukan berfungsi untuk mengatur suatu wilayah teritorial, melainkan membangun citra positif di persepsi publik.Branding tidak dapat mengubah suatu kota, wilayah, atau negara, namun dapat membantu secara keseluruhan di dunia persaingan yang semakin kompetitif salah satunya adalah industri pariwisata (Cavia, 2013). Hal tersebut dijelaskan juga oleh Wally Olins, yaitu:

"You do not change people's perceptions of a country with advertising. You change people's perceptions by finding the truth, finding an ideal that embraces that truth and putting it through everything they do."

\section{The Hexagon of Competitive Identity Nation Branding}

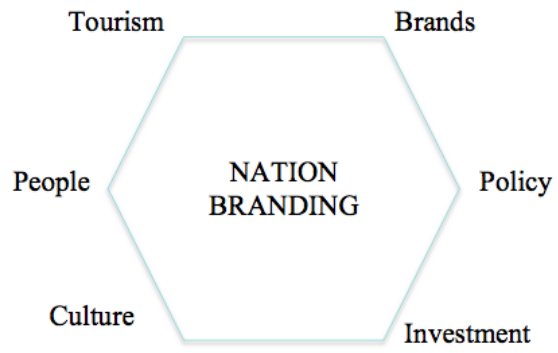

Sumber: (Simon Anholt, 2003)

Selain empat aspek kunci branding, dalam nation branding hexagon terdapat 6 elemen kunci Nation branding (Anholt, 2007), yaitu:

1. Merek Ekspor (Export Brands)
Menunjukkan persepsi publik terhadap citra atau image dari produk barang dan jasa suatu negara, serta mengukur tingkat permintaan produk dari negara tersebut oleh publik atau konsumen.Merek ekspor dipandang sebagai untuk mencari keinginan suatu individu untuk mempunyai permintaan terhadap suatu barang hingga melakukan pembelian dan merasa puas dengan produk dari suatu negara.

2. Peraturan Pemerintahan (Government, Foreign and Domestic Policy)

Menggambarkan opini publik terhadap sebuah negara terkait kompetensi, keadilan, komitmen mengatasi masalah global, dan kepercayaan publik pada pemerintah. Ketika suatu peraturan bersinergi dengan channel yang lain akan lebih cepat untuk memperkenalkan suatu posisi tempat, salah satunya adalah negara kepada komunitas global. Peraturan pemerintah mempunyai beberapa aspek seperti keyakinan pada isu-isu global, hak asasi manusia, sistem hukum keadilan kriminal, dan isu lainya yang terkait dengan peraturan pemerintahan

3. Kultur dan Warisan Budaya (Culture and Heritage) Mengukur persepsi global terhadap warisan dan budaya negara peninggalan masa lampau juga penghormatan terhadap budaya saat ini.Nation branding yang sukses membutuhkan suatu integrasi dari budaya negara yang artistik sejalan untuk 
memperoleh perbedaan keunikan dan ketahanan pada suatu negara. Kultur dan warisan budaya terdiri dari 3 (tiga) kategori, yaitu peninggalan sejarah (heritage), pemandangan alam (landscape), dan seni (arts). Masyarakat (People).

- Peninggalan sejarah (Heritage), Peninggalan sejarah yaitu mencakup sejarah suatu negara, tradisi, dan arsitektur. Kesulitan hal tersebut adalah seiring perkembangan waktu, peninggalan sejarah bertentangan dengan karakter negara yang modern.

- Pemandangan Alam (Landscape),Pemandanga $\mathrm{n}$ alam mempunyai kekuatan yang sangat penting. Tidak hanya sebagai suatu nilai tambah atau simbol yang diberikan pada sebuah negara, namun juga berkaitan dengan emosi masyarakat.

- Seni (The Arts), beberapa elemen pada suatu seni memainkan peran penting dalam identitas nasional (national identity) seperti sastra, musik, artefak budaya. Seni didalam suatu negara tidak sematamata berdiri sendiri, namun ada integrasi yang kuat antara para seniman serta sejarah seni dalam suatu negara itu sendiri. Seperti, musik indie, perfilman, dan kuliner dapat menjadi strategi keseluruhan untuk memperbaiki citra reputasi negara.

4. Masyarakat (People)

Mengukur reputasi masyarakat terkait kompetensi, pendidikan, keterbukaan, dan keramahan atau sikap dari suatu penduduk kepada para wisatawan atau pengunjung lain serta melihat derajat diskriminasi pada masyarakat di suatu negara.

Masyarakat merupakan aspek penting dalam pengukuran suatu negara, mengetahui bahwa negara tidak akan berdiri tanpa ada sumber daya manusia didalamnya. Aspekaspek yang mengukur hal ini adalah kepribadian dan sikap sosial masyarakat

5. Pariwisata (Tourism) Mengukur tingkat ketertarikan publik mengunjungi suatu negara. Pariwisata terjadi melalui sistem push dan pullyang mempengaruhi tingkat ketertarikan wisatawan. Hal tersebut juga bertujuan untuk mengidentifikasi keadaan alam atau bangunan-bangunan modern yang menarik perhatian para wisatawan (Gfk Custom Research North America, 2011).Komponenkomponen pada pariwisata atau tourism adalah fasilitasfasilitas lingkungan alam atau buatan manusia (infrastruktur) hingga kuliner hingga iklim atau cuaca suatu wilayah.

6. Investasi dan Imigrasi (Investment and Immigration) Mengukur tingkat ketertarikan publik untuk tinggal dan belajar di negara tersebut juga menunjukkan kondisi sosial maupun ekonomi pada negara 
tersebut.Investasi disini memiliki beberapa aspek seperti infrastrukur pada suatu daerah, biaya hidup, ekonomi, kondisi lingkungan, kebebasan, jasa kesehatan, dan keamanan \& risiko (safety \& risk) serta iklim suatu wilayah.terhadap suatu negara sebagai sebuah merek.

\section{Hipotesis Penelitian}

Berdasarkan rumusan masalah diatas, penulis memperoleh hipotesis sementara, yaitu :

1. Persepsi masyarakat kota Bandung mengenai nation branding cukup baik.

2. Preferensi masyarakat kota Bandung terhadap tujuan wisata domestic belum sepenuhnya sesuai ekspektasi, karena banyak juga preferensi wisata luar negeri yang diminati oleh masyarakat kota Bandung.

3. Pengaruh Branding " Pesona Indonesia" terhadap prefensi tujuan wisata masyarakat Kota Bandung cukup postif.

\section{Metode Penelitian}

\section{Model Penelitian}

Pada penelitian ini penulis menggunakan metode deskriptif eksplanatory. Metode deskriptif yaitu metode yang digunakan untuk menggambarkan atau menganalisis suatu hasil penelitian. Metode deksriptif explanatorydimulai dengan mengumpulkan data, menganalisis data, dan menginterpretasikannya (Sugiyono, 2012).

\section{Populasi}

Populasi dalam penelitian ini adalah masyarakat yang bertempat tinggal di Kota Bandung.Sedangkan sampel adalah bagian dari jumlah dan karakteristik yang dimiliki oleh populasi tersebut (Sugiyono, 2012).Teknik pengambilan sampel pada penelitian ini adalah purposive sampling.Purposive sampling adalah teknik penentuan sampel dengan pertimbangan khusus, sehingga dijadikan sampel (Sekaran \& Bougie, 2012:252).Sedangkan sampel yang digunakan termasuk kedalam nonprobability sampling.Nonprobability sampling adalah desain sampel pada elemen dari populasi tidak memiliki probabilitias apapun untuk dipilih menjadi subjek sampel (Sekaran \& Bougie, 2013).Penentuan sampel dengan pertimbangan khusus sehingga dapat layak jika dijadikan sampel. Beberapa pertimbangan tertentu yaitu masyarakat Kota Bandung yang berusia 18 - 50 tahun, hal tersebut dipilih karena mampu untuk melakukan perjalanan wisata, selain itu masyarakat yang suka dengan perjalanan wisata baik ke dalam atau keluar negeri, serta memiliki pendapatan di atas Rp1.000.000 ke atas dengan pertimbangan bahwa mereka dapat melakukan perjalanan ke dalam negeri atau luar negeri baik itu dari menabung atau lain sebagainya.

Dalam penelitian ini, masyarakat Kota Bandung yang dijadikan sebagai populasi, tidak diketahui berapa jumlahnya. Perhitungan sampel menggunakan rumus Aaker, Kumar, dan Day (2013:336), apabila populasi tidak dapat diketahui secara pasti, pengambilan sampel dapat dilakukan dengan menggunakan rumus sebagai berikut

$$
n=\frac{0.25 \times z^{2}}{e^{2}}
$$

Keterangan :

$\mathrm{n}=$ Ukuran Sampel Minimum

$\mathrm{z}=$ nilai $\mathrm{z}$ untuk interval kepercayaan yang ditentukan

$e=$ Tingkat Kesalahan (error) sebesar 0.10 Asumsi sampling error adalah $10 \%$ dan interval kepercayaan sebesar 95\%, didapatkan angka sebesar 1.96 daru tabel Z. 
Dengan menggunakan rumus tersebut didapatkan jumlah sampel (n) adalah sebagai berikut :

$$
n=\frac{0.25 \times 1.96^{2}}{0.1^{2}}
$$

$$
n=96.04 \text { atau minimal } 97 \text { responden }
$$

Berdasarkan perhitungan tersebut, jumlah sampel yang digunakan sebanyak 97 responden.Jumlah sampel menjadi 150 responden untuk mengantisipasi jika terdapat responden yang tidak memenuhi kriteria.

\section{Definisi Operasional Variabel}

Operasionalisasi variabel dalam penelitian ini terbagi menjadi 2 (dua), yaitu :

1. Operasionalisasi variabel Nation Branding (X) dengan berdasarkan teori Anholt, S dan Gfk (2011) sebagai Variabel Independen (Variabel Bebas) yaitu variabel yang mempengaruhi variabel terikat baik secara positif maupun negative (Sekaran \& Bougie, 2013).

2. Operasionalisasivariabel Preferensi Konsumen (Y) dengan berdasarkan teori Kottler \& Keller (2012) sebagai Variabel Dependen (Variabel Terikat) yaitu variabel utama yang menjadi investigasi (Sekaran \& Bougie, 2013).

\section{Metode Analisis Data}

\section{Uji Validitas}

Validitas adalah derajat ketepatan antara data yang terjadi pada objek penelitian dengan data yang dapat dilaporkan oleh peneliti (Sugiyono, 2012).Suatu instrument dikatakan valid bila mampu mengukur konsep yang ingin diukur, tinggi rendahnya validitas instrumen menunjukkan sejauh mana terkumpulnya suatu data tidak menyimpang dari gambaran variabel yang sudah diukur.Pengujian ini dihitung menggunakan SPSS (Statistical Product and Service Solution) 16.0.Jika ada item yang tidak memenuhi syarat, item tersebut tidak akan diteliti lebih lanjut. Kriteria syarat - syarat yang harus dipenuhi yaitu :

- Jika $r \geq 0.30$, item-item pertanyaan dari kuesioner adalah valid

- Jika $\quad r \leq 0.30$, item-item pertanyaan dari kuesioner adalah tidak valid

\section{Uji Reliabilitas}

Uji Reliabilitas adalah suatu alat ukur yang bertujuan untuk mengukur sejauh mana hasil pengukuran bersifat tetap, dapat dipercaya sebagai alat pengukur data, serta terbebas dari kesalahan pengukuran (measurement error) untuk melakukan uji reabilitas digunakan teknik Alpha Cronbach. Pengujian uji realibilitas penelitian ini akan menggunakan software SPSS 16.0 (Sekaran \& Bougie, 2013). Menurut Sekaran dan Bougie (2010:325), alat ukur dapat dikatakan sebagai reliable apabila nilai Alpha Cronbach $\geq 0.6$, dengan kriteria sebagai berikut :

- $\alpha:<0.6$ : Reliabilitas secara umum tidak baik

- $\quad \alpha$ : 0.6-0.8 : Reliabilitas secara umum dapat diterima

- $\alpha:>0.8$ : Reliabilitas secara umum baik

\section{Analisis Regresi Linear Berganda}

Yang digunakan dalam penelitian ini yaitu analisis linear berganda.Analisis linear berganda merupakan suatu teknik statistik yang dapat digunakan untuk menganalisis hubungan antara satu variabel dependen tunggal dengan beberapa variabel independen.Dalam penelitian ini yang menggunakan 
analisis linear berganda adalah pengaruh nation branding "Pesona Indonesia" terhadap preferensi konsumen. Hipotesis pertama yaitu :

Persamaan analisis linear berganda tersebut adalah :

$$
\begin{gathered}
\mathrm{Y}=b_{0}+b_{1} X_{1}+b_{2} X_{2}+b_{3} X_{3}+ \\
b_{4} X_{4}+b_{5} X_{5}+b_{6} X_{6}+e
\end{gathered}
$$

Keterangan :

$$
\begin{aligned}
& \mathrm{Y}=\text { Preferensi Konsumen } \\
& b_{1}, b_{2}, \ldots, b_{6}=\text { Koefisien } \\
& X 1=\text { Brands } \\
& X 2=\text { Policy } \\
& X 3=\text { Investment } \\
& X 4=\text { Culture } \\
& X 5=\text { People } \\
& X 6=\text { Tourism } \\
& \text { Hipotesis dalam penelitian } \\
& \text { ini, yaitu } \\
& : H_{0}: \beta_{1} \leq 0 \text { Nation branding } \\
& \text { tidak berpengaruh positif } \\
& \text { terhadap preferensi tujuan } \\
& \text { wisata } \\
& H_{0}: \beta_{1} \geq 0 \text { Nation branding } \\
& \text { berpengaruh positif terhadap } \\
& \text { preferensi tujuan wisata. }
\end{aligned}
$$

\section{Hasil Penelitian dan Pembahasan}

Berikut ini akan dibahas seluruh hasil pengujian dan jawaban responden pada penelitian ini. Hal-hal yang akan dibahas, yaitu:

1. Profil responden,

2. Analisis Pengaruh Positif Nation Branding "Pesona Indonesia" Terhadap Preferensi Tujuan Wisata

3. Hasil uji Normalitas dan Multikolinieritas

4. Analisis Pengaruh Nation Branding "Pesona Indonesia" Terhadap Preferensi Tujuan Wisata.

\section{Analisis Profil Responden Berdasarkan Usia dan Jenis Kelamin.}

- Responden terbanyak yang mengisi kuesioner ini adalah berada di rentang usia 18-25 Tahun, hal tersebut dapat diinterpretasikan bahwa umur dengan rentang usia 18-25 Tahun adalah yang lebih banyak mengisi kuesioner dengan alasan memberikan waktu beberapa kali dalam setiap tahunnya untuk berlibur.

- Sehubungan dengan profil responden berdasarkan usia, diketahui bahwa responden terbanyak adalah perempuan. hal ini dikarenakan dalam pengisian online form dan penyebaran kuesioner lebih banyak dilakukan ke perempuan dibandingkan dengan laki - laki.

- Berdasarkan hasil profil responden berdasarkan pekerjaan mayoritas terbanyak adalah Pelajar/Mahasiswa selanjutnya adalah Pegawai Swasta. Berdasarkan data tersebut dapat diinterpretasikan sebagian besar kuesioner ini memiliki mayoritas umur 18-25 tahun, karena Pelajar/Mahasiswa lebih banyak melakukan perjalanan wisata dibandingkan responden yang sudah bekerja.

2. Analisis Pengaruh Positif Nation Branding “Pesona Indonesia” terhadap Preferensi Tujuan Wisata

Terdapat 6 (enam) variabel dari nation branding yang ditanyakan kepada responden, yaitu Exports, Governance, Investment, Culture, People, dan Tourism. Namun dalam jurnal ini ada 3 variabel yang mewakili, untuk menjelaskan lebih rinci, pengaruh poisitif nation branding

"Pesona 
Indonesia"terhadap preferensi tujuan wisata.

\section{Exports}

Berikut ini adalah pernyataan kuesioner dan jawaban responden terhadap barang - barang yang dihasilkan oleh masyarakat Indonesia, yaitu:

Pernyataan : Produk lokal dari Indonesia memiliki citra yang baik dan menarik perhatian, seperti Cinderamata, produk fashion, dsb.

Mayoritas responden memiliki pendapat yang setuju bahwa produk lokal dari Indonesia memiliki citra yang baik dan menarik perhatian.Hal tersebut dapat diinterpretasikan bahwa Masyarakat Kota Bandung sebagian besar cenderung positf dengan produk - produk lokal Indonesia.Produk - produk lokal yang dihasilkan adalah bagian dari industri kreatif yang sedang berkembang.Kenyataannya, produk merek Indonesia sudah banyak mendapat pengakuan dari dunia Internasional sebagai produk yang unik dan berkualitas. Selain itu, saat ini Industri kreatif sangat didukung oleh Kementerian Pariwisata dan Ekonomi Kreatif untuk dapat meningkatkan kualitasdan pengembangan produk baik industri kreatif kecil atau besar untuk meningkatkan aset yang dimiliki oleh Indonesia untuk menaikan citra Indonesia dalam pandangan responden yaitu Masyarakat Indonesia.Hal tersebut mempengaruhi persepsi responden cukup baik dengan produk lokal Indonesia.

\section{Governance}

Pernyataan : Keamanan di suatu daerah baik. (Pencurian, Perampokan saat perjalan wisata).
Dari pernyataan diatas, mayoritas Persepsi Responden Terhadap Keamanan di Suatu Daerah memiliki jawaban kurang baik atau tidak setuju. Berdasarkan pola urutan jawaban yang mengacak, dapat diinterpretasikan bahwa tidak seluruh daerah di Indonesia memiliki tingkat keamanan yang baik.Bahwa, tidak meratanya tingkat kemanan di Indonesia berhubungan dengan Pemerintah Daerah yang terkait.Tingkat keaman tersebut adalah tindak kejahatan, seperti pencurian, perampokan, penjambretan, pemalakan, pembunuhan, korupsi, dsb. Misalnya, kota Bandung memiliki keamanan yang baik namun kondisi kemanan di Jakarta masih mengkhwatirkan dan meragukan karena merupakan kota yang besar. Terlebih hal tersebut juga mempengaruhi persepsi masyarakat mengenai daerahdaerah kecil yang belum terjamah dimana aparatur di daerah tersebut belum banyak seperti layaknya kota besar. Bahwa, keamanan disuatu daerah mempengaruhi kunjungan wisatawan. Contohnya adalah ketika terjadinya Bom Bali pada Tahun 2002 yang memicu adanya dampak keraguan bagi wisatawan nusantara ataupun internasional untuk pergi ke Kota Bali atau Indonesia. Hal tersebut menjadi tolok ukur suatunation branding bahwa keamanan suatu daerah memiliki dampak besar dalam kunjungan wisatawan.

\section{Investment}

Pernyataan : Daerah - daerah di Indonesia memiliki kualitas fasilitas prasarana umum pendukung wisata yang baik, seperti Hotel, Toilet Umum, 
Tempat Ibadah, Tempat Makan, sarana kesehatan, transportasi, dsb.

\section{Persepsi Responden Terhadap Fasilitas di Daerah Indonesia}

Responden memiliki jawaban yang berhimpitan antara Setuju dan Raguragu.Hal tersebut dapat dikarenakan fasilitas-fasilitas yang dimiliki suatu daerah tidak seluruhnya baik. Hal itu juga didukung oleh pengalaman kunjungan wisata responden yang berbeda - beda. Fasilitas umum seperti sarana transportasi (kereta api, bus, kendaraan umum, kapal laut, pesawat, dsb), sarana kesehatan (puskesmas, balai kesehatan, rumah sakit, dsb), dan fasilitas pendukun pariwisata (hotel, toilet umum, tempat ibadah, tempat makan, dsb) kurang memadai di Indonesia terlebih didaerah-daerah kecil yang belum terjamah oleh pemerintah pusat dan kurangnya dukungan antar pemangku pariwisata dan pemerintah daerah. Sehingga, fasilitasfasilitas tersebut tidaklah merata dan tersebar dengan kualitas standardisasiyang baik di seluruh Indonesia.

\section{Uji Normalitas}

Uji normalitas merupakan salah satu syarat untuk menggunakanuji regresi baik regresi linear sederhana ataupun berganda.Jika uji ini dilanggar maka data tidak valid.Uji normalitas pada penelitian ini menggunakan metode Grafik Plot.

Berikut ini adalah hasil pengujian normalitas pada penelitian ini :

1. Uji Normalitas pengaruh positif nation branding terhadap preferensi tujuan wisata.Pada Gambar diatas, dapat dilihat bahwa titik - titik (plot) mengikuti dan mendekati garis diagonal. Hal tersebut dapat diartikan bahwa data jawaban responden berdistribusi normal.

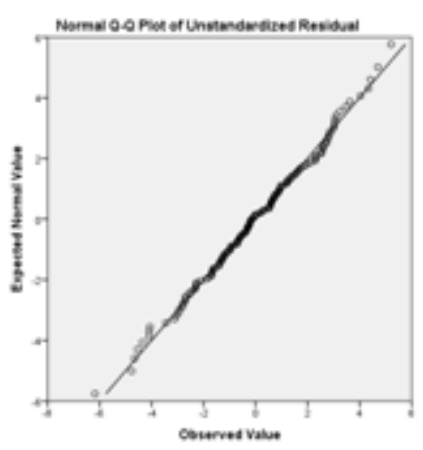

\section{Uji Multikolinearitas}

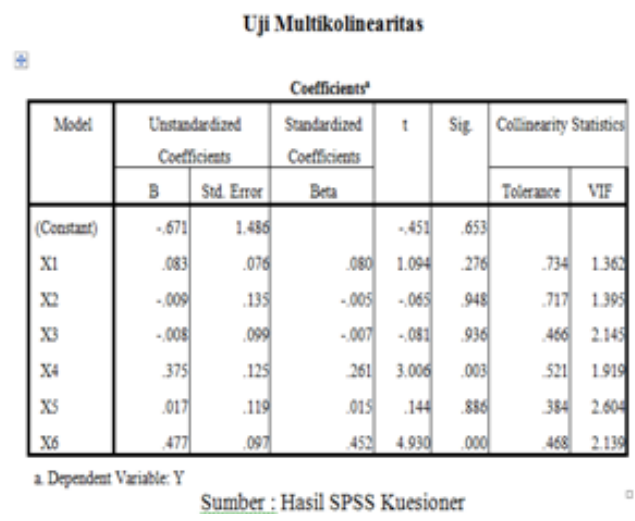

\section{Sumber : Hasil SPSS Kuesioner}

Uji Multikolinieritas untuk megetahui ada atau tidaknya hubungan antara beberapa atau semua variabel yang menjelaskan dalam model regresi.Jika pada model terdapat multikolinearitas maka model tersebut memiliki kesalahanstandar yang cukup besar sehingga koefisien tidak dapat ditaksir dengan ketepatan yang tinggi.

Uji Multikolinearitas hanya digunakan untuk regresi linear berganda, sehingga pada penelitian ini pengujian multikolinearitas digunakan untuk pengaruh positif nation branding terhadap preferensi tujuan wisata.Pada tabel 4.43, dapat dilihat bahwa nilai VIF seluruh variabel $<10$ dan memiliki nilai tolerance $>0.10$. Hal tersebut dapat menunjukan bahwa tidak terjadi multikolinearitas pada penelitian ini. 


\section{Analisis Pengaruh Nation Branding}

Terhadap Preferensi Tujuan Wisata

Analisis pengaruh nation branding (X) terhadap preferensi tujuan wisata (Y) menggunakan analisis regresi linear berganda, yaitu X1 adalah Exports, X2 adalah Governance, X3 adalah Investment, X4 adalah Culture, X5 adalah People, X6 adalah Tourism. Analisis ini juga menggunakan alat perhitungan SPSS 16.0.berikut ini adalah hasil analisis pengaruh nation branding terhadap preferensi tujuan wisata.

Tabel 1

Uji Normalitas Pengaruh Positif Nation

Branding Terhadap Preferensi Tujuan Wisata

Pengaruh Nabion Branding (X) Terhadap Preferemai Twjuan Wisata (N)
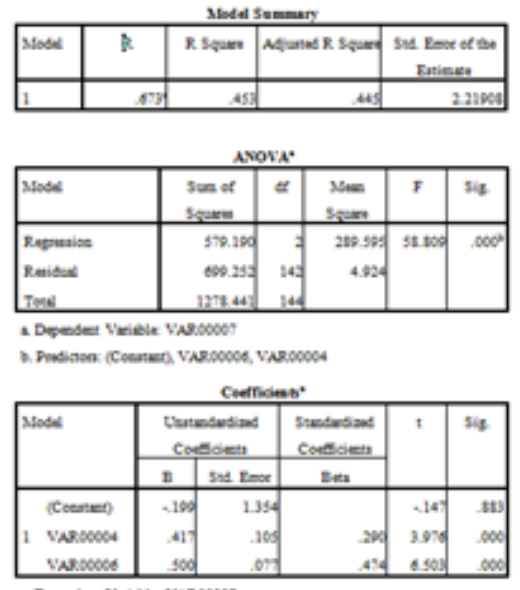

a Degender Vkiele Var.soget

Sumber: Hasil SPSS Kuesioner

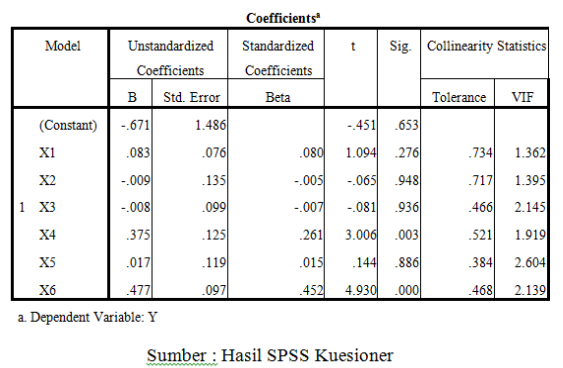

1. Pengujian Hipotesis :
$H_{0}: \beta_{1} \leq 0$

Nation branding tidak berpengaruh positif terhadap preferensi tujuan wisata

$H_{0}: \beta_{1} \geq 0$

Nation branding berpengaruh positif terhadap preferensi tujuan wisata

2. Tingkat Signifikasi $5 \%$ atau 0.05

3. Uji Statistik :

a. Pengujian ANOVA $=0.000$

Dalam hal ini meramalkan pengaruh pengaruh positif nation branding terhadap preferensi tujuan wisata, karena nilai yang diperoleh kurang dari 0.05.

b. Pengujian Signifikansi

- Exports $=0.276$

Exports tidak berpengaruh positif terhadap preferensi tujuan wisata (Ho diterima), karena nilainya lebih dari 0.05 .

- Governance $=0.948$

Governance tidak berpengaruh positif terhadap preferensi tujuan wisata (Ho diterima), karena nilainya lebih dari 0.05 .

- Investment $=0.936$

Investment tidak

berpengaruh positif terhadap preferensi tujuan wisata (Ho diterima), karena nilainya lebih dari 0.05 .

c. Pengujian Korelasi

Pada tabel 4.45, $\mathrm{R}$ sebesar 0.673 . variabel yang tidak signifikan telah dihapus oleh karena itu didapatkan keeratan hubungan pengaruh positif antara nation branding terhadap preferensi tujuan wisata sebesar 0.0673 menunjukkan hubungan positif yang cukup erat. 
4. Besarnya Pengaruh

Besarnya pengaruh dapat dilihat dari tabel Model Summary pada nilai Adjusted $R$-Square sebesar 0.445.hal tersebut bahwa pengaruh nation branding terhadap preferensi tujuan wisata sebesar $44.5 \%$. sisanya dipengaruhi oleh faktor-faktor lain.

\section{Simpulan dan Saran}

\section{Simpulan}

Berdasarkan penelitian dan pembahasan yang penulis telah lakukan pada bab-bab sebelumnya, berikut ini merupakan kesimpulan yang dapat penulis simpulkan : Berdasarkan hasil wawancara dengan responden, terdapat permasalahan mengenai destinasi-destinasi wisata di Indonesia yang kesiapannya kurang matang, belum merata, dan terkonsentrasi. Indonesia yang memiliki potensi luar biasa besar dalam kekayaan alam, budaya, dan segala keunikan yang dimiliki seharusnya mampu menarik wisatawan nusantara lebih optimal dan dapat berkompetisi dengan destinasi pariwisata diluar dalam memperebutkan potensi pasar wisatawan. Adanya berbagai keterbatasan pada aksesibilitas dan konektivitas ke destinasi wisata yang berada di daerah-daerah belum terjamah, namun memiliki potensi yang baik sebagai destinasi wisata, serta keterbatasan ketersediaan dan kualitas fasilitas pendukung wisata antar pemangku kepentingan dibidang pariwisata yang relatif masih kurang. Selain itu, responden meragukan kemanan dan ketertiban disuatu daerah-daerah di Indonesia, hal tersebut dapat diinterpretasikan bahwa penyebaran ketertiban dan keamanan disuatu daerah belum menyebar secara merata di seluruh bagian daerah.Selaras dengan hal tersebut, terdapat beberapa persepsi kurang positif dalam destinasi wisata di Indonesia. Responden mengakui bahwa kekayaan alam yang dimiliki Indonesia memang memiliki daya tarik, akan tetapi keterjangkuan, kemudahan, dan kenyamanan kunjungan wisatawan di destinasi wisata diragukan. Sehubungan dengan hal tersebut, upaya membangun pencitraan Indonesia secara internal melalui branding pariwisata Indonesia, yaitu dengan tagline "Pesona Indonesia" memiliki awareness dan pencitraanyang masih lemah. Hal tersebut juga didukung dengan jawaban responden yang memiliki keraguan untuk lebih memilih berwisata kedalam negerinya sendiri dibandingkan keluar negeri.

1.Persepsi terhadap nation branding sudah cukup baik. Karena, secara umum responden yang menjawab setuju pada pernyataan - pernyataan positif mengenai nation branding. Namun, hal tersebut belum dapat dikatakan memuaskan karena pada beberapa pernyataan mendapatkan jawaban ragu-ragu. Berikut ini dijelaskan kesimpulan secara terperinci, yaitu :

a. Exports, produk-produk lokal dari Indonesia sudah memiliki citra yang baik dan menarik perhatian dimata responden, bahwa produk lokal memiliki. Produk lokal yang memiliki keunikan dan kreatif, membuat responden mencari dan berminat dengan produk lokal Indonesia.

b. Governance, kelemahan pada standar kualitas antar pemangku kepentingan dalam kepariwisataan belum optimal, sehingga responden ragu-ragu dengan sistem keamanan dan ketertiban yang terdapat pada suatu daerah destinasi.

c. Investment masih diragukan pada keterjangkauan dan aksesibilitas kesuatu daerah destinasi. Hal ini dikarenakan masih terbatasnya transportasi dan infrastruktur kesuatu destinasi wisata di Indonesia. Responden meyakini bahwa daerah destinasi wisata sudah memiliki fasilitas dan informasi wisata yang baik, namun tidak didukung dengan aksesibilitas yang memadai.

- Pengaruh positif pada persepsi responden sudah cukup baik. Hal ini terlihat pada banyaknya 
responden yang menjawab setuju pada hampir pernyataanpernyataan positif mengenai nation branding Indonesia. Namun, jawaban ragu-ragu pun menduduki posisi ke-2 (dua) jawaban terbanyak. Persepsi responden terhadap governance mendapat jawaban tertinggi ragu-ragu.

- Preferensi destinasi wisata ke negeri sendiri memiliki perbedaan tipis antara setuju dan ragu-ragu. Hal tersebut belum dapat dikatakan hasil yang baik karena jawaban ragu - ragu pada beberapa pernyataan hampi menyeimbangi jawaban yang setuju.

- Hasil pengujian hipotesis yaitu dengan menggunakan analisisregresi linear berganda menunjukan bahwa exports, governance, dan investment, berpengaruh positif terhadap preferensi destinasi wisata Indonesia.

\section{Keterbatasan Penelitian}

Batasan dan kekurangan dari hasil penelitian ataupun proses penelitian yang masih belum maksimal menjawab permasalahan ataupun fenomena yang terjadi, sehingga menjadi masukan untuk penelitian selanjutnya.

\section{Saran}

Berikut ini adalah saran penulis berdasarkan hasil penelitian ini untuk meningkatkan kinerja pemerintah pada nation brandingnya kepada wisatawan nusantara :

1. Untuk meningkatkan persepsi wisatawan mengenai keamanan dan ketertiban (governance) pada daerah destinasi wisata, perlu dukungan dan kerja sama yang optimal mengenai kesiapan masyarakat di sekitar destinasi pariwisata, aparatur, dan pemangku kepentingan pariwsata, sehingga sinergi tersebut menciptakan keamanan , ketertiban, bersih, nyaman, ramah - tamah, dan memberikan kenangan tersendiri agar persepsi wisatawan di setiap daerah menjadi positif.

2. Wisatawan mengakui bahwa Indonesia adalah tempat yang memiliki keindahan alam luar dan budaya yang luar biasa, namun hal tersebut tidak menjamin wisatawan untuk memilih tujuan destinasi utama dibandingkan ke luar negeri dalam tujuan wisata, hal itu salah satunya dapat disebabkan dengan infrastruktur pada aksesibilitas dan konektivitas yang belum memadai karena luasnya Indonesia sebagai negara kepulauan. Sehubungan dengan hal tersebut, pemerintah pusat dapat menginstruksikan kepada pemerintah dan dinas pariwisata setiap daerah untuk menggalakkan dan memperbaiki infrastruktur daerah pariwisatanya masing-masing. Misalnya, memperbaiki setiap jalan kearah destinasi wisata setiap daerah, meningkatkan kualitas kenyamanan dan kuantitas jalurjalur dan transportasi kesuatu daerah, fasilitas-fasilitas kepariwisataan, dan sumber daya manusia yang berkompetitif di setiap daerah pelosok Indonesia. Sehingga menghasilkan sinergi yang baik antara pemerintah dan pemangku kepentingan kepariwisataan di setiap daerah.

3. Awareness tagline "Pesona Indonesia" yang masih lemah, dapat dilakukan dengan pemasaran yang massif, luas, kuat, serta taktis melalui strategi yang lebih efektif dan konsisten. Pasalnya, strategi pemasaran tersebut harus selaras dengan kenyataan yang ada, yaitu seperti kondisi setiap destinasi wisata Indonesia bahwa dalam penyampaian core message yang 
dimiliki Indonesia haruslah padu. Sehingga dapat membentuk personality danidentity yang baik di persepsi masyarakat Indonesia itu sendiri.

4. Keamanan negara yang masih memiliki citra kurang baik di mata wisatawan nusantara, diharuskan seluruh pemangku wisata dan pemerintah daerah setempat memberikan perhatian yang lebih dalam usaha menjaga serta memelihara keamanan setiap daerahnya masing-masing, yaitu dengan cara melalui tata tertib dan peraturan yang berlaku disertai tindakan secara nyata, berkelanjutan, dan konsisten.

5. Pembenahan infrasktruktur harus dilakukan secara terintegrasi dan massif. Pemerintah harus memikirkan bagaimana agar perjalanan wisata ke dalam negeri sendiri dapat lebih murah dibandingkan ke negeri tetangga. Dengan begitu, wisatawan nusantara akan lebih memilih negeri sendiri yang memang terbukti lebih kaya dan berpotensi dibandingkan negara tetangga.

6. Sumber Daya Manusia dalam kepariwisataan harus lebih ditingkatkan disetiap daerahdaerah. Tidak hanya di Bali, Lombok, atau daerah tujuan wisata yang memang popular saja. Seharusnya, daerah-daerah yang berpotensi namun belum terkenal juga memiliki sumber daya manusia yang andal dan berpotensi, sehingga wisatawan nusantara yang memang lebih mengenal negaranya sendiri akan lebih memilih untuk berwisata ke dalam negeri.

7. Budaya Indonesia yang kaya harus tetap didukung dan terus dikembangkan. Selain ituu dijaga oleh masyarakat Indonesia itu sendiri. Karena tingkat kepedulian masyarakat terhadap seni dan budaya terus menurun seiring perkembangan jaman yang semakin modern, globalisasi yang tinggi, serta gaya hidup yang berubah.

\section{Daftar Pustaka}

Akotia, M. S. (2011). Country Branding. International Journal of Business Strategy (Vol. 11/2). Austin, 2-3.

Bisniswisata.co.id. (2015, Juni 20). (K. Sujatmiko, Editor, H. Sabri, Producer, \& BisnisWisata.co.id) Retrieved September 07, 2016, from Pariwsata Indonesia:

http://bisniswisata.co.id/bisniswisata/p ariwisata-indonesia/Bisniswisata.co.id. (2016, Januari 14). Bisnis Wisata Berita Wisata Utama. (K. Sujatmiko, Editor, H. S. Sulistyo, Producer, \& Redaksi Bisnis Wisata) Retrieved September 06, 2016, from 2015, Jumlah Wisatawan Indonesia ke Luar Negeri Meningkat: http://bisniswisata.co.id/2015-jumlahwisatawan-indonesia-ke-luar-negerimeningkat/

Baloglu, S. M. (1999). U.S International Pleasure Travelers' Image of Four Mediterranean Destinations: A Comparison of Visitors and Nonvisitors. Journal of Travel Research, 38 (No.2), 144 - 152.

Beerli et al. (2007). Self Congruity and Destination Choice, 2-4.

Cavia, L. (2013). Destination Brands and Website Evaluation. A Research Methodology .

Dutawisata.co.id. (2016, Oktober 17). "Wonderful Indonesia" atau "Pesona Indonesia". (H. Sukoyo, Editor) Retrieved Oktober 18, 2016, from dutawisata.co: http://www.dutawisata.co/wonderfulindonesia-atau-pesona-indonesia/ 
Diplomasiekonomi.kemlu.go.id. (2016, 03 15). diplomasiekonomi.kemlu.go.id. Retrieved 09 12, 2016, from Upaya Promosi Potensi Pariwisata Indonesia Untuk Meningkatkan Perekonomian Nasional:

https://diplomasiekonomi.kemlu.go.id/ images/capbuilddiplomat/Paparan $\% 20$ KEMPAR.pdf

Etzel, Walker, Stanton. (2013). Consumer Preference and Consumer Buying . (Pushpavathani.K, $\&$

Kumaradeepan.V, Eds.) Asian Journal of Marketing \& Management Research, 2, 58.

Kementerian Pariwisata. (2016). Laporan Akuntabilitas Kinerja: Kementerian Pariwisata Tahun 2015. (K. Pariwisata, Ed.) DKI Jakarta, Indonesia: Biro Perencanaan dan Keuangan Sekretariat Kementerian Pariwisata, 13-19.

Kotler, P., \& Keller, L. K. (2012). Marketing Management (14th ed ed., Vol. 14th ed). (E. Svendsen, Ed.) Upper Saddle River, New Jersey: Prentice Hall.

Kemenpar.go.id. (2016, 02). kemenpar.go.id. (B. P.-K. Pariwisata, Ed.) Retrieved 09 11, 2016, from Laporan Akuntabilitas Kinerja Kementerian Pariwisata Tahun 2015: http://www.kemenpar.go.id/userfiles/fi le/test/LAKIP-

KEMENPAR\%202015.pdf

Kementerian Pariwisata RI. (2016, 0104$).$ kemenpar.go.id. (K. Pariwisata, Producer, \& Kementerian Pariwisata) Retrieved 09 11, 2016, from Ranking Devisa Pariwisa Terhadap Komoditas Ekspor Lainnya: http://www.kemenpar.go.id/asp/detil.a $\mathrm{sp} ? \mathrm{c}=117 \& \mathrm{id}=1198$

Kementerian Pariwsata. (2015). Buku Panduan Logo. Jakarta, Indonesia.

Koranbisnis.com. (2015, 06 09). koranbisnis.com. (S. Widodo, Editor, \& Bisnis Indonesia) Retrieved 09 13, 2016, from Tajuk Bisnis Indonesia:
Jangan Lupakan Wisatawan Lokal: http://koran.bisnis.com/read/20150609 /245/441455/tajuk-bisnis-indonesiajangan-lupakan-wisatawan-lokal

Liputan6.com, B. (2014, Agustus 14). Bisnis Liputan 6. (A. Wiranuari, Editor, \& Liputan6.com) Retrieved September 06, 2016, from Wawancara Mari Elka: Malaysia vs Wonderful Indonesia:

http://bisnis.liputan6.com/read/208914 4/wawancara-mari-elka-malaysiatruly-asia-vs-wonderful-indonesia

LaMondia, Snell, Bhat. $(2009,11)$. Traveler Behavior and Values Analysis in the Context of Vacation Destination and Travel Mode Choices: A European UnionCase Study, 136-153.

Malhotra, N. K., \& Birks, D. F. (2007). Marketing Research: An Applied Approach (The European Edition ed.). (R. Roussan, Ed.) Edinburgh Gate, Harlow, England: Prentice Hall, Inc., A Pearson Education Company.

Nicolau and Mas. (2006). The Influence of Distance and Prices on The Choice of Tourism Destinations: The Moderating Role of Motivations. Tourism Management, 27, 982-996.

Pikiran-rakyat.com. (2014, Desember 30). Indonesia Butuh Country Branding untuk Menarik Wisatawan. (Munady/A-147, Editor, \& Pikiran Rakyat) Retrieved Agustus 30, 2016, from Pikiran Rakyat: http://www.pikiranrakyat.com/wisata/2014/12/30/310275/ indonesia-butuh-country-brandinguntuk-menarik-wisatawan

Rajpurohit, R. \&. (n.d.). Consumer Preference and Satisfaction Towards Various Mobile Phone Service Providers. Gurukul Business Review (GBR) , 1-11.

Sekaran, U., \& Bougie, R. (2013). Research Method For Business (Sixth ed., Vol. Sixth). United Kingdom: John Wiley and Sons. 
Sugiyono. (2012). Metode Penelitian Kuantitatif, Kualitatif, dan $R \& D$. Bandung, Jawa Barat, Indonesia: Alfabeta.

Simon Anholt. (2003). Brands and Branding. (R. C. Simmons, Ed.) Branding Places and Nations , 213.

Swa.co.id. (2013, 03 06). swa.co.id. (R. Wiraspati, Editor, \& SWA - Trends Business Research) Retrieved 09 13, 2016, from BCG: Pertumbuhan Kelas Menengah Atas Indonesia Meluas Ke Daerah:http://swa.co.id/swa/trends/bus iness-research/bcg-pertumbuhan-kelasmenengah-atas-indonesia-meluas-kedaerah

Theodhori, Oriole \& Eleina, Qirici. (2014). The Impact of Destination Branding to Tourist Behavior Albania in Focus. Journal of Knowledge Management, Economics and Information Technology

Wikipedia. (2016, 07 31). id.wikipedia.org. Retrieved 09 11， 2016， from Indonesia:

https://id.wikipedia.org/wiki/Indonesia 